\title{
The Rectification of (Modern) Names: Jürgen Habermas Meets Confucius-Fixing Our Broken Political Discourse
}

\author{
Joe Old1, Robert Ferrell ${ }^{2}$ \\ ${ }^{1}$ English Department, El Paso Community College, EI Paso, Texas, USA \\ ${ }^{2}$ Philosophy Department, El Paso Community College, El Paso, Texas, USA \\ Email: joeold12@gmail.com, rbtferrell@sbcglobal.net
}

Received 21 January 2015; accepted 9 February 2015; published 11 February 2015

Copyright (C) 2015 by authors and Scientific Research Publishing Inc.

This work is licensed under the Creative Commons Attribution International License (CC BY). http://creativecommons.org/licenses/by/4.0/

(c) (i) Open Access

\section{Abstract}

This paper explores four concepts to point a way out of the political morass in which we find ourselves at the middle of the second decade of the 21st century: 1) The "rectification of names", a concept of Confucius that should have the highest priority in such a situation as now prevails in the United States; 2) Carl Schmitt's concept of "the political"; 3) A new reading of James Madison's Federalist Paper No. 51 that envisions "creating a will in the community independent of the majority, that is of society itself"; 4) And Jürgen Habermas's "communicative action theory", which would serve to engender genuinely democratic discourse in our political system, combined with a critique by former US Supreme Court Justice John Paul Stevens of corporate influence in our politics, which together represent a significant step toward finally achieving the Confucian ideal. Finally, this paper offers a mechanism and an institution for realizing the goal that the new Madison reading suggests, something that is consistent with the best values of our nation most grandly conceived, and a social media method-afforded by movements such as the Arab Spring and the Occupy Wall Street Movement-for triggering that mechanism and resulting institution, one that is analogous to the Han dynasty's development of the Shuo Wen Dictionary, and one that would function in a way similar to that envisioned by Han dynasty thinkers.

\section{Keywords}

Confucius, "Rectification of Names" (zhèngmíng一正名), Jürgen Habermas, "Lifeworld”, "System", James Madison, Carl Schmitt, George Orwell, John Milton, US Supreme Court Justice John Paul Stevens, Communicative Action Theory, "The Political", Discourse Ethics, Federalist Papers, Shuo Wen Jiezi 


\section{Introduction}

Few will argue with the proposition that our political discourse in the United States is at a new low, certainly for recent times. We need only to mention the names of Sarah Palin, the Republican vice-presidential candidate in the 2008 election, and US Rep. Michele Bachmann (R-MN), a candidate for the Republican presidential nomination, who has used violent political rhetoric, e.g., “don’t retreat, reload” and "armed and dangerous” respectively. But they are not alone. Members of the Tea Party rage against the "tyranny" of the federal government. And recently we've seen the intransigence of the Republicans, first, in the debate over raising the federal debt ceiling threatening to throw the country into default, with potentially catastrophic consequences, and, second, in their abject refusal to address unemployment in the face of an ongoing national crisis, the obvious aim being to ensure President Barack Obama’s defeat in 2012.

One example of the absurdity of Republican political discourse occurred on April 8, 2011, when US Senator John Kyl (R-AZ), stood on the floor of the Senate and said that abortion was "over 90 percent of what Planned Parenthood does". Called on the statement, Kyl's office issued a clarification that "his remark was not intended to be a factual statement” (Seitz-Wald, 2011). The incident received brief media attention and then faded. Both Kyl's comment and the clarification issued by his office are iconic and all too common in contemporary American political discourse: Not only was the statement “defective” as discourse (in that it didn't say what was really meant), it was an example of instrumental reason (it intended to achieve a goal, independent of other, possibly contradictory implications), but it was non-democratic (it apparently intended to use Kyl's authority as a senator to foreclose further debate and discussion). To the extent that this is normal, something is clearly amiss with contemporary American political discourse.

\section{Confucius's "Rectification of Names" and Madison's "Will of Society"}

Is there a way out of the morass threatening to become the political norm in our country? The solution we propose involves synthesizing an idea articulated by James Madison, at least in one logical reading, in Federalist Paper No. 51 (Publius, 1788), with a second idea, this one advocated by the Chinese philosopher Confucius, specifically the “rectification of names”, zhèngmíng-正名 (Chan, 1969: p. 40). The result would be a set of consensus principles and a means of realizing them — a determined center of gravity in the body politic, perhaps drawn together via the powerful forge of social media at an opportune moment afforded by the Occupy Wall Street Movement, itself partially inspired by the Arab Spring. Such principles will be advocated and defended on the basis of a positive interpretation of the "friend-enemy" distinction articulated in 1932 by Carl Schmitt in The Concept of the Political, (Schmitt, 1996, 2007) but with an opposite intent to Schmitt's; i.e., democratic as opposed to fascist.

We believe that Confucius's concept of the rectification of names, zhèngmíng一正名, is both a worthy goal and a worthy standard for our political system to strive for, and we propose approaching that ideal through a possible reading of an ambiguous statement in James Madison's Federalist Paper No. 51. There Madison says that the factions are likely to emerge in the government under the then-proposed Constitution and that as a result there is the need "to guard one part of the society against the injustice of the other part" and that the solution is to create "a will in the community independent of the majority, that is, of the society itself” (Publius, 1788). In our interpretation, Madison's recommendation would be read, not as Madison himself said it should be read, as representing the approach made by "governments possessing an hereditary or self-appointed authority”, i.e., a monarchy. Rather, the statement can be read to mean “... by creating a will in the community independent of the majority that is [a will] of the society itself...” We argue that this could be done institutionally by creating a faction, Madison’s ultimate solution in any case (Publius, 1788), within the democratic wing of the Democratic Party, one that would practice a new kind of "rectified" and honest discourse in which, true to the Confucian ideal, names would be rectified, that is, would match their corresponding reality, and all of the subsequent social turmoil Confucius wanted to avoid by this doctrine would indeed be avoided. We further suggest that modern social media could be a technological mechanism for recording and keeping political discourse straight and publically available-a contemporary analog to the Shuo Wen Dictionary conceived by Han dynasty leaders — and that Jürgen Habermas's approach to the crisis of modern society via his theory of communicative action could help lead our political discourse to a rationality not evident even in recent decades.

\section{The World-Historical Dimensions of the Problem}

This paper, then, aims at a world-historical solution to problems with our contemporary political discourse, and 
particularly the problem of corporate dominance of our legal and political system, which has resulted in overwhelming benefit to the rich and powerful.

\subsection{Solon and Thomas More Understand the Historical Problem}

To illustrate how long such a problem has been recognized—and the resulting injustices perpetuated—one need only to look at the comments of historian/biographer Plutarch comments on the seventh century BCE Greek lawmaker Solon, who is famously credited with having reformed Athenian law preventing citizens from being sold into slavery for debts. Writing in the late first and early second century CE, Plutarch (c. 46 CE-120 CE) made this point about the operation of vested interests in Solon's day (and indeed in ours):

The remission of debts was peculiar to Solon; it was his great means for confirming the citizens' liberty; for a mere law to give all men equal rights is but useless, if the poor must sacrifice those rights to their debts, and, in the very seats and sanctuaries of equality, the courts of justice, the office of state, and the public discussions be more than anywhere at the beck and bidding of the rich (Plutarch, 1952: p. 87).

The emphasized text sounds as valid today as it did in Plutarch's or Solon's day. Habermas also found the same problem identified by Thomas More (1478-1535) in his Utopia, published in 1516. There he registered an almost identical complaint:

And so, when I examine and consider all the flourishing republics in the world today, believe me, nothing comes to mind except the conspiracy of the rich, who seek their own advantage under the name and title of the republic. They also devise and think up all sorts of ways and means to hold onto their ill-gotten gains with no fear of losing them, and then hire the labor of all the poor at the lowest price and abuse them. When once the rich have decreed that all these devices are to be observed in the public name (in other words, in the name of the poor too), they then become laws (Habermas, 1974: p. 53).

So there is a sense in which problems keep being put off, even as there is economic, technological, cultural, and other development. In the current socioeconomic reality, political maneuvering aims to destroy Medicare and Medicaid while, at the same time-through the so-called "Ryan budget", for example-extending tax cuts to millionaires and billionaires. But can such problems as identified by Solon and Thomas More-and many others, incidentally—be put off indefinitely?

In their book Winner-Take-All Politics: How Washington Made the Rich Richer and Turned Its Back on the Middle Class, Jacob S. Hacker and Paul Pierson trace the origin of today's political crisis to the 1970s, that being the point when the shift began that produced the politics their book's subtitle spells out (Hacker \& Pierson, 2010). However, we would point out that a high point in this rising tide of out-of-control political rhetoric leading to today's Tea Party politics is Ronald Reagan's first inaugural speech. In that Jan. 20, 1981, speech, Reagan said, "In this present crisis, government is not the solution to our problem; government is the problem" (Reagan, 1981). Reagan's assertion has become a Republican mantra and the extreme right's ill-conceived agenda, iconically illustrated today by right-wing activist Grover Norquist, whose widely quoted goal is to "to reduce [government] to the size where I can drag it into the bathroom and drown it in the bathtub” (Wikipedia, 2014b). Norquist’s notorious pledge has committed the majority of Republicans in Congress never to raise taxes, thus contributing to the lock-step Republican resistance to addressing both the deficit and unemployment problems the nation faces today. But it is Ronald Reagan who must in large measure bear the responsibility for the tone of today's political rhetoric and for the uncritical acceptance of the right-wing dictate to "get the government off our backs", blindly shrinking it as if that were an end itself, independent of the positive role government plays in our society. The 2011 debate(s) over raising the federal debt limit illustrates the problem of our political discourse, particularly with the Republicans insisting that the only negotiations possible are those giving them everything they want and budging not an inch on increasing revenues. And it's not clear the hardliners even recognize the consequences their intransigence potentially entails in global economic terms.

\subsection{Orwell States the Communication Dynamics of the Problem}

No one has written more insightfully about the problems of language in politics, and vice versa, than George Orwell in his 1946 masterpiece "Politics and the English Language" (Orwell, 1946). His central point is that 
corrupt political discourse leads to politicians who do not think when they communicate and audiences who are too easily manipulated. His essay ideally sees "language as an instrument for expressing and not for concealing or preventing thought”. Clearly in Orwell’s formulation of the problem of his day-which seems even truer now in ours where electronic communication is pervasive-the easy manipulation of populations is as much a problem as the ignorance, deviance, and even corruption of the politicians themselves. Orwell noted that a "reduced state of consciousness, if not indispensable, is at any rate favorable to political conformity". Such a state of consciousness is an irony in a world flooded with communications that should increase consciousness, but too often have the opposite effects of distracting and even numbing consciousness.

Orwell stated the issue well, but he opened up space for a more elaborate discussion of the implications of the problems. The Confucian "rectification of names" gives us an excellent means for furthering the diagnosis. Of course, Americans should not be asked to change their manner of political speech by taking up that of a remote, fifth-century BCE Chinese philosopher, but that does not invalidate this Confucian concept as a heuristic device for contemporary thinkers. The "rectification of names", one of Confucius's most profound concepts and one whose implementation has really never been tried in the sense conceived by Confucius, is a sign pointing us to a way out of the mess our political discourse is in today, even a banner under which we can formulate issues in a way that helps envision real solutions to them. Although Confucius never held a major political office, when he was asked what he would do first if he had such an office, he stated that his first priority would be a "rectification of names”. Wing-tsit Chan's classic translation of the original passage from the Analects explains that Confucius believed that social disorder can stem from the failure to call things by their proper names. The pressing need was thus zhèngmíng-正名—literally “rectification of terms” (Chan, 1969: p. 40). If the names of things are not correct, Confucius then would say that "language will not be in accord with truth. If language is not in accord with truth, then things cannot be accomplished". The end result, omitting the Chinese cultural elements, is that "people will not know how to move hand or foot”, i.e., chaos and confusion result in society. To use a modern example, the "Clear Skies Act of 2003" is badly misnamed, but any objective view of the act must lead to the recognition that it was not a recipe for "clear skies”, but for a weakening of environmental regulations and, in fact, dirtier skies. The same is true of the “Clean Water Cooperative Federalism Act of 2011” (Kennedy Jr., 2011).

Political discourse today is so riddled with incorrect "names” (i.e., with terms that do not really mean what they seem to say) that it's a wonder anything gets done, and in fact, in the 111th Congress, the goal of the Republicans was to see that nothing got done-except some emergency measures to prevent a probable global financial collapse. They also watered down the legislation that did pass, and on the eve of 2010 mid-term elections, Kentucky Sen. Mitch McConnell, the Republican leader, said, "The single most important thing we want to achieve is for President [Barack] Obama to be a one-term president” (Herszenhorn, 2010). And working against Obama’s every project and every effort, even if these had been Republican projects and goals before, Republicans in the Senate in a recent Congress sponsored an unprecedented number of filibusters to stop Democratic legislation (Packer, 2010: p. 47) —and they continue their obstruction. The most prominent political contribution of the Republican Party during the entire Obama Administration has been obstructionism.

What, in general, would be most subject to a "rectification of names" in a system amenable to such change? For starters, any statement reflecting distortion, hypocrisy, lies, propaganda, ideology, or “political fiction” generally needs "rectifying". Analysts use such terms to un-do the corrosive effect of concealment, distortion, and intentionally obscurant language. Any critical maneuver that lets us penetrate the fog of ideological distortions, hypocrisy, and lies so that we can clearly see what is both clouding our communications and turning our terms and names for things into unreliable guides to the world - thus creating the chaos and confusion both Confucius and Orwell warned of - would constitute a rectification. Expressions such as “death tax”, "socialism”, "tax and spend”, and "tyranny" are good prospects for "rectification". (Though such expressions may create "chaos" in the minds of the naïve voters who fall for ideological statements containing them, those same statements help create "order" for the special interests who benefit from the policies such terms justify. Many ordinary people spout Tea Party slogans in demonstrations organized and funded by the brothers David and Charles Koch, whose anti-governmental lobbying efforts directly benefit them. See Jane Mayer's August 30, 2010, New Yorker article titled “The Billionaire Brothers Who Are Waging a War Against Obama” (Mayer, 2010). Another example is political rallies that pretend to be "grassroots", but which are in fact underwritten by numerous organizations funded by and serving corporate interests and are more correctly thought of as "astroturf” events, the term originally being coined by US Sen. Lloyd Bentsen, according to an article in Wikipedia (Wikipedia, 2014a)). 
We argue that, following Habermasian discourse ethics, we should systematically and fearlessly lay out all our political narratives - both right and left, both ours and theirs-about our government, our economics, and our social system, and all with the Confucian intent, bolstered by the contemporary need, of rectifying the terms in the narratives, eliminating their obfuscating elements and clearly revealing their flaws. It is important to find the weaknesses in our own narratives, as well. Our commitment to “truth” should be the same as Milton's when he inveighed against licensing in Areopagitica: “And though all the winds of doctrine were let loose to play upon the earth, so Truth be in the field, we do ingloriously, by licensing and prohibiting, to misdoubt her strength. Let her and Falsehood grapple: who ever knew Truth put to the worse in a free and open encounter” (Milton, 1644; spelling modernized). In good-faith politics, Milton’s standard should be the touchstone.

\section{Carl Schmitt's Approach Rejected}

Before suggesting some issues that are good candidates for such a "rectification”, we should ask what might result from a satisfactory engagement of such a project. The answer to that question will also give us the institutional mechanism for moving forward. We don’t need a "new” political narrative, but a revitalized one that restores our commitment to the best of what this country has evolved as a historical and political project, such narrative becoming the basis for concrete action now and in the future. We use the word "political” not just in terms of party conflict, but in a larger, trans-party sense, related though not identical to Carl Schmitt's use of the term in his 1932 work The Concept of the Political (Schmitt, 1996, 2007: pp. 26-30). We step back to what he conceptualized as truly political ground and make the friend-enemy distinction once again, but here the distinction is made in light of the greatest political values that have emerged over the trajectory of our history.

Political corruption is one way to articulate political values through action, but such values, along with racism, slavery, and the celebration of secession from the union, self-evidently do not represent the best and greatest political concepts the US political experiment has produced. Rather, what is meant here is the set of values and practices pertaining to freedoms and protections, constitutional and otherwise, particularly in expanding the franchise-now under serious attack in many states (American Civil Liberties Union, 2011), but which are now in danger of being overturned in the confused state of our contemporary political discourse. Just look at the number of states who passed voter repression measures in the wake of the US Supreme Court's gutting of the Voting Rights Act of 1965 in its June 25, 2013, decision in Shelby County v. Holder.

When we refer to Schmitt's friend-enemy distinction, we are not contemplating Nixon's “enemies list”, though perhaps we do include the Republican modus operandi today suggested in Alan Wolfe's essay about Schmitt's ideas in "A Fascist Philosopher Helps Us Understand Contemporary Politics”- and Republicans do seem to be practicing something very like what Schmitt advocates, as Wolfe suggests (Wolfe, 2004). Actually, Schmitt envisioned a realm above the practice of politics where "the political" referenced the survival of some entity and where friends were those forces supporting it and enemies, those who would destroy it (Schmitt, 1996, 2007: pp. 26-30). In that rarefied, existential sense, above practical politics, but back on the plane of political and existential ideals representing the best our country stands for-as exemplified, say, in Martin Luther King's "Letter from the Birmingham Jail” and the "I Have a Dream” speech, where he called the nation to account based on the highest values it had articulated for itself_-on that plane, we must ask: What forces are "friends" and what forces are "enemies"? The friends being whatever advances the country's best interests grandly conceived (civil rights, voting rights, social security, etc.); the enemies, whatever corrodes those rights (the tyranny of kings, priests, special interests that capture the mechanisms of government). In addition to Martin Luther King's statements, of course, are numerous other statements of our historical ideals as they have evolved historically since our system emerged in the constitutional form it took in 1789 following the chaos created by the Articles of Confederation.

Once those "friends" and "enemies" have been articulated, we can then set about politics in the practical, everyday sense of the term, based on a platform of such rectified terms. What is needed, though, is a vehicle for the realization and implementation of our set of restored, revitalized, clarified political ideals. One reading of James Madison's Federalist Paper No. 51, offers us exactly the vehicle we need, particularly the passage that Madison offered as the means "to guard one part of the society against the injustice of the other part".

\section{James Madison's Federalist Paper No. 51}

Madison's oft quoted passage reads as follows: 
There are but two methods of providing against this evil: the one by creating a will in the community independent of the majority that is, of the society itself; the other, by comprehending in the society so many separate descriptions of citizens as will render an unjust combination of a majority of the whole very improbable, if not impracticable. The first method prevails in all governments possessing a hereditary or self-appointed authority (Publius, 1788; emphasis added).

The italicized portion of the quote above is the passage of interest. It can be read in two ways:

Reading A: “... by creating a will in the community independent of the majority that is [independent] of the society itself...”

Reading B: “. .. by creating a will in the community independent of the majority that is [a will] of the society itself...”

There is no linguistic imperative to make the meaning of the key passage in Federalist No. 51 agree with Reading A. In fact, Reading B opens up Federalist No. 51 to another vision entirely, one that is much needed and one that is more appropriate now than it would have been in the era when the fight over adopting the Constitution occurred. (The thinking then, clearly, was that the Congress and other governmental institutions would in fact work to ensure that the will of society itself was captured and implemented. And for purposes of argument, we will give them credit for actually believing that. It did not turn out that way, as even a casual understanding of corporate influence in our political and governmental system reveals.) The vision that Reading B opens up to us now — and that reading itself—is more appropriate than Reading A because of our contemporary political realities.

The vision offered by Reading B is appropriate, first, because there is no political force that represents the "will in the community... [the will] of society itself". While Congress should represent society as a whole, it manifestly does not, and the real constituents that most members of congress represent (Republican and Democratic, House and Senate, at both federal and state levels) are those interests whose money guarantees access. This notion is usually trivialized with the word "only" inserted as if to be a substantial reassurance: "political contributions only buy access"- and, therefore, do not constitute bribes. But that access is real and powerful, and the money comes with strings. Legislators then try to rewrite the redistricting rules, not to guarantee free, open, and fair elections, but the opposite: to perpetuate themselves in power free of future political challenges. They pass laws ostensibly to "protect" the system from the over-hyped and under-proven bogeyman of the political system—voter fraudwith the real intent being to disenfranchise voters who line up on the opposite (i.e., Democratic) side. These powerful interests both prompted and supported the legislation that produced the Citizens United decision by the US Supreme Court that guaranteed unlimited political contributions to politicians who protect corporate interests. And the examples are legion of how corporate interests get protection, from the gutting of financial reform following the 2008 financial meltdown that triggered the worldwide economic catastrophe to continued corporate welfare.

There is no institution representing, standing for, looking out for, "the will of the society itself"-particularly that will expressed in the historical evolution of our system which has, painfully and slowly at times, protected civil rights, extended the franchise to women, and protected the weak in our society. But there has recently been a stirring in the body politic — caused by a pent-up resentment against injustices—manifesting itself in the Occupy Wall Street Movement, itself inspired by the so-called "Arab Spring” and inspiring comparable movements across the globe. Aided by social media, which was seminal in facilitating and energizing the Arab Spring, the Occupy Wall Street Movement often finds its voice beneath placards denouncing "corporate greed". This somewhat inchoate and amorphous movement, brimming as it is with energy, is the natural vehicle to take up the idea being presented here.

Initially the authors of this article envisioned the potentially resulting institution as arising as a "faction" (with appropriate irony) in one of the main political parties, probably the Democratic one. But clearly the Occupy Wall Street Movement has the potential to facilitate what is being called for here- - the emergence of an institution that can answer and resist the dominant factions now in control of our governmental and political institutions. This new movement can, operating entirely within our best political traditions and within the law, seize democratic control of those institutions as an expression of the "will of society itself" and return the country to a political, economic, and governmental course consistent with and appropriate to our best political values most grandly conceived. 
Moreover while Madison was confident that the unwashed majority could not threaten the rights and properties of the individuals and minorities, what he failed to realize was that the combinations that did seize control of our political system would threaten to supplant "the will of society itself". What Madison and the other founders, fearing "democracy" - primarily for what democracies in the states could do to wealthy minorities (Wood, 2009: p. 31) — did not conceive of was that any faction could put the entire society at danger, a situation we arguably have today. Nor did he apparently conceive of the kind of faction that we are calling for here using an interpretation of his words, a faction that could represent society as a whole, i.e., the faction with society's best interests at heart, much like a legislative body can sit as a "committee of the whole"-and independent of the narrower interests of any majority he could conceive of. Such a "faction of the whole" would aim to protect society's interests as a whole - at least in the reading proposed in this paper. That could even be its sole function. Under this reading, the "will in the community" would be "of society itself", and it would be "independent of the majority".

If we were to create a will in the community... [a will] of the society itself, lodging it in an institution independent of the majority, one that would hold even the strongest political party to account, it could result in the development of a broad base of the population acting as "friends" of the terms (or names) "rectified" to eliminate the confusions that Confucius (and Orwell) identified. This new entity embodying the will of society itself is the mechanism for redressing the perversions which special interests have initiated or capitalized on, Santa Clara County v. Southern Pacific Railroad, which granted corporations the rights of persons under the "equal protection clause” of the Fourteenth Amendment, being Exhibit No. 1 in this regard.

\subsection{Originating a New Statement of the "Will of Society"}

Such an independent political institution as is being called for here could originate in the Occupy Wall Street Movement, and could even designate itself as a third party, but it should be committed to a restored, revitalized set of political ideals — the rectified political lexicon—and that institution, that faction, augmented by those of good will from other parties, would best represent "the will of society itself" and could wrest control of the government from the corporate hands it is largely now in.

Many of the terms which should be considered from the vantage point of undistorted meaning relate to elitism, populism, freedom, trickle-down economics, and socialism, but others as well, such as whether government ought to be "run like a business". In short, the major issues confronting our society today should through democratic discourse be analyzed for the distortions in the terms in which they are couched. There have been many attempts to come to grips with this problem of words corresponding in meaning to an acceptable standard, from the early Greeks through the Founding Fathers, and today with contemporary thinkers, from Jacques Derrida's indeterminacy of meaning to Jürgen Habermas's quest for an ideal speech situation. The deconstructive method might have use in identifying ideological distortion and/or misinterpretation, but would be of little help in determining a rational standard. Habermas's approach, however, relies upon rational self-interest by the participants leading to agreed-upon meanings. In a pluralistic situation with more than a few most charitably described as reactionary and ill-informed, one must be careful about expecting this ever to occur automatically. Even the brief references to this problem in the Federalist papers showed the writers' inability to imagine today's world where political parties dominate, with voting along strict party lines, and "talking points" provided by think tanks dedicated to winning above all or by ideologically controlled media. Clearly, what is needed for rational decision making is an independent, objective fact-checking "agency"-operating on Habermasian discourse ethics (see below)—and one that maps perfectly over the "faction" representing society as a whole and, therefore, the will of society expressed through historical development—and not a majority captured, say, by the Tea Party, which claims to revere the Constitution and is often both ahistorical and inaccurate in its claims, leading Garrett Epps, a professor of law at the University of Baltimore, in an article titled "Stealing the Constitution" to urge citizens to actually know the content of our founding documents and stating that the stakes are all too clear: "Read the Constitution and measure it against the absurd claims we hear every day", Epps argues, "This is a matter of life and death for our Republic" (Epps, 2011).

The Platonic/idealistic formalism of our heritage sought to affix correct and appropriate definitions to political terms, leading to misguided attempts to construct what was imagined to be the "original intent" of the founders, i.e., something "fixed" or "immutable". US Supreme Court Justice Antonin Scalia claims to base his decisions upon a strict interpretation of the clear meanings of the Founding Fathers. But Confucius, as presented by David 
Hall and Roger Ames in their important work, Thinking Through Confucius (Hall \& Ames, 1987), sought to convince listeners of an understanding of received values that did not depend upon a fixed reality, but rather an appropriate one with reference to the classical approaches-in an "American" and contemporary context, our best values most grandly conceived. By making an "appropriate" reading of Madison, one that fits and answers the contemporary political need for creating will in the community, (a will) of the society itself, one that is related to and anchored in our original values as they have historically evolved, our system would enhance its ability to survive under many different circumstances—and remain true to those values.

\subsection{Resonance with American Enlightenment Values}

This approach should have resonance for an America committed to the Constitution, however drastically changed the circumstances of our situation or the situation of any future society dedicated to those values. Unlike the originary situation, women and property-less non-white men can now vote, and in many ways our society differs from the one set up and countenanced by those Founding Fathers-yet it implements their best values. When Thomas Jefferson penned the words, "We hold these truths to be self-evident", it did not seem self-evident that slaves, women, and Native Americans should be considered as having been "created equal" or having "certain inalienable rights". In spite of the vicissitudes of history—and many wrong turns, including those leading to the Civil War - we have largely corrected these inequities, but we are curiously in danger of implementing other inequities because the mechanisms of power, the institutions of government, are not in the hands of a segment of the population expressing the will of the society itself. In fact, the forces dominating our political system clearly represent their own narrow, primarily economic and power interests. Hence we are at risk of losing the very values the founders intended to institutionalize.

\section{Failing Institutions}

It is clear that our institutions are failing us.

Confucius's problem was that of convincing a small cadre in leadership capacity at court. In today's pluralistic society, the populace at large must be convinced in a world full of dirty tricks and falsehoods. The leaders of the Latter Han dynasty (206 CE-220 CE) attempted their rectification of names-as an entry in Wikipedia tantalizingly suggests - by means of the celebrated Shuo Wen Jiezi, a dictionary created by XuShen (Wikipedia, 2011). If the Chinese could attempt a rectification of names by means of a dictionary, thus allowing scholars at court to manipulate the world based on their Confucian values, surely we can find a mechanism to modify our institutions in such a way that would let us institutionalize a will in the community, a will of society itself. A repository not unlike Wikipedia perhaps, but organized around the most pressing issues of a society at any moment, would be a start, and the power which social media has manifested in the so-called "Arab Spring” provides a model. And given our existing institutional base supplemented by the World Wide Web and by bending social media into service as the means of accessing — and asserting—society's will, we have far more powerful tools at hand than the Han dynasty's Shuo Wen Jiezi, and we have the potential of actually achieving the Confucian dream of bringing about a genuine "rectification of names"-based on Habermas's program of discourse ethics and Communicative Action Theory.

Most Americans apprised of the issues in clear and distinct terms could easily see, for example, that

- Oil companies, among the most powerful and successful economic entities in history, no longer need subsidizing by the American people.

- Raising taxes on the wealthiest Americans is preferable to cancelling valuable and viable social programs.

- Destroying our resources in the name of short-term corporate profits made with an eye blinded to social costs of environmental destruction is poor stewardship of the Earth.

- ... and so forth to the $\boldsymbol{n}$ th issue.

The $\boldsymbol{n}$ th issue being that discrete last one with the power to negate the will in the community. It would not be hard to fill in the list of issues and start the discussion in a democratic public forum that would almost inexorably lead to a consensus, hence rectifying our political discourse and setting the stage for corrective, rectifying action that would logically follow. Populating a list of issues should be the first step in the new discourse. To ideas suggested above, we could add whether politics is inherently bad, as suggested by the oft-lodged charge of "playing politics"; whether "welfare" in its corporate form should be seen for what it appears to be; whether 
corporations should in fact be considered persons; whether "government take-over" is a legitimate characterization of the valid exercise of federal and state authority in matters of public interest; whether "letting the market do it" is a viable solution to social problems; and so forth. The list goes on. However, it is not difficult to imagine a point at which society, once truthfully apprised of the issues in clear and non-obscurant terms, expresses its will and moves to action in its own interest—as opposed to special interests.

\section{Enter Jürgen Habermas and Communicative Action Theory}

We argue here that a comparable faction to the Tea Party, one organized on the left and based on rational and democratic political discourse advocated by Habermas, can gain the support of a majority of citizens of this nation and set the political agenda for this country, not only in the short run, but indefinitely, once Habermas's principles become known, correcting the disastrous tendency of our political discourse and the dangerous tendency of our non-democratic, corporate-dominated politics and economics.

Although Habermas is largely unknown in the United States, he is widely considered the most important sociologist and philosopher at work in the world today (Bohman \& Rehg, 2011). Habermas's communicative action theory, with its accompanying discourse ethics, not only offers a healthier political discourse than we now have, but one that it both democratic and strives to curb instrumental reason, which skews our entire political system to the service of corporate interests. The rest of this paper will elucidate these claims.

Born in 1929, Habermas grew up in Nazi Germany, with the Nuremberg trials and the soul-searching of German society over its nightmare adventure with the Third Reich forming the backdrop of his entry into adulthood. When he was 24, Habermas wrote a paper calling out the philosopher Martin Heidegger for his support of the Nazis while the rector at the University of Freiburg (Bohman \& Rehg, 2011). When Heidegger not only ignored the young intellectual but published a book with an "Introduction" alluding to the "inner truth and greatness" of National Socialism, Habermas is said to have turned his back on German philosophy, and began to explore the positive aspects of constitutional democracies (Bohman \& Rehg, 2011). In fact, a commitment to democracy has long been a hallmark of Habermas's approach to philosophy and to sociology. It is embedded in the "principle of discourse" (D) that bolsters his theory of communicative action. The expression (D) holds that "the normative validity [in communicative action] is dependent upon agreement of all as participants in a practical (in other words moral) discourse, which is to say that only agreement that is based on truly open and rational debate counts. To spell out the nature of discourse a little more precisely, this entails that all competent speakers and actors are allowed to take part; everyone can question anything that is said, and may introduce new assertions (including assertions of their attitudes, desires, and needs) as they see fit, and no speaker may be coerced into withholding or withdrawing their participation” (Edgar, 2006: 45-46).

And in his recent work related to the role of law in a just society, democracy is also at work in the formulation of laws: "A law can only be considered to be legitimate if the sovereign who debates and offers justification for the law is at one and the same time the citizen who will be subject to that law. This entails that any just society must secure certain rights for its citizens that guarantee their participation in the discursive process that leads to good law” (Edgar, 2006: p. 84).

\section{Habermas's "Lifeworld" and "System"}

\subsection{The "Lifeworld"}

Two core concepts in Habermas's analysis of society are "lifeworld" and "system", and as social realities they are in tension and in conflict. The notion of lifeworld is taken from Edmund Husserl (1859-1938), who developed phenomenology to combat the prevalence of scientific and technological abstraction, which he saw a concealing the more significant aspects of human existence. Such abstractions constitute the "instrumental reason", which is at the heart of the other key component of society, "system". The latter is the realm of goal-oriented activity of organizations such as government, corporations, political parties, labor unions, advocacy groups, trade groups, etc. They have only their short term interests at heart, and this constitutes their danger.

But according to James Gordon Finlayson's Habermas: A Very Short Introduction, "The problem is that although the system is embedded in and depends on the lifeworld, the former tends to encroach upon, to displace and even destroy, the latter" (Finlayson, 2005: p. 56). The colorful term that Habermas has for this is "colonization". 
The system is blind to any goals other than its own and tries to take over, or "colonize" lifeworld resources. Says Finlayson,

As the domain of the lifeworld shrinks, a whole gamut of what Habermas calls "social pathologies" arise, which include, but are not limited to, the negative effects of markets on the nonmarket domains they colonize (Finlayson, 2005: p. 56).

But before exploring the problems of system, let us be clear about the importance and the potential of the lifeworld —and what is at stake. We might state it thus: Lifeworld is not just a philosophical abstraction. It represents the complete array of creative, intellectual, cultural, sociological, physical, sexual, psychological, artistic, scientific, mathematical, and philosophical possibilities of human existence, present, past, and future. The existential ground of all human life conceived in its vastest potentiality is at stake with the colonization of lifeworld: the finest human thinking, doing, creating, performing, acting in an almost infinite number of cultural dimensions. It is all of the potentialities of human existence, realized and unrealized, even those beyond our ability to imagine now. It is the uncarved block of Taoism, the "all things luxuriantly present" of Buddhism as Chinese Neo-Confucian thinker Wang Yang-ming (1471-1529) conceived it (Wang, 1963).

That survey of social pathologies Finlayson refers to builds on the work of Emile Durkheim and Max Weber, both of whom saw increasing problems as societies became more complex, respectively through a division of labor and rationalization of society, and includes anomie, disintegration, alienation, demoralization, and social instability (Finlayson, 2005: p. 57). But colonization is what Habermas's communicative action theory aims to combat.

\subsection{The "System"}

There is no shortage of advocates for the system. The leaders of the array of organizations and institutions listed above are by definition system advocates. Society's most pressing contemporary need is to curb system incursions into lifeworld. In her book Habermas: Rescuing the Public Sphere, Pauline Johnson frames the problem this way:

Modernization processes have systematized and rendered explicit certain distinct modes of rationalization, but a pathological modern development threatens to engulf our capacity to rationalize our actions with respect to the goal of critical self-reflection by a one-sided focus on a world rationalized in accordance with technical interests (Johnson, 2011: p. 41).

And because lifeworld problems are not like system problems, the kind of reason needed to solve them is different. Johnson describes the lifeworld, really the world of culture, this way:

Cultural differentiation offers a place for a new kind of rationality that also shapes a modern experience. This is a world in which all assertions, descriptions, claims, and propositions are contentious, open to criticism and review on the basis of their conformity to idealized and differentiated descriptions of their validity" (Johnson, 2011: p. 48).

The problem, however, is that somehow, over our history, the institutions of the Constitution, the Congress especially, but at times also the Supreme Court and even the Presidency, are captured by powerful system elements, historically corporations, and the actors (congressmen, senator, judges, presidents) who should be protecting the lifeworld, are in fact often doing corporate bidding. Associate US Supreme Court Justice John Paul Stevens, who wrote a powerful dissent in the Citizens United case over political campaign contributions, scored the majority of the court for having supported corporate interests over the people of the United States. He said:

It might also be added that corporations have no consciences, no beliefs, no feelings, no thoughts, no desires. Corporations help structure and facilitate the activities of human beings, to be sure, and their "personhood" often serves as a useful legal fiction. But they are not themselves members of "We the People" by whom and for whom our Constitution was established (Stevens, 2010).

Stevens' critique is in fact a blueprint for how to attack the overweening role that corporations have assumed in our society. He further wrote in his dissent:

Although they make enormous contributions to our society, corporations are not actually members of it. They cannot vote or run for office. Because they may be managed and controlled by nonresidents, their interests 
may conflict in fundamental respects with the interests of eligible voters. The financial resources, legal structure, and instrumental orientation of corporations raise legitimate concerns about their role in the electoral process. Our lawmakers have a compelling constitutional basis, if not also a democratic duty, to take measures designed to guard against the potentially deleterious effects of corporate spending in local and national races (Stevens, 2010).

The key problem with unlimited corporate participation in the election process, of course, is corruption coming from private interests interfering with and even coopting the government for their own ends. This is a concern going back to the framers of the Constitution. "Thomas Jefferson famously fretted that corporations would subvert the Republic", Stevens wrote, footnoting the statement with a quote from a letter Jefferson wrote in 1816: "I hope we shall... crush in [its] birth the aristocracy of our monied corporations which dare already to challenge our government to a trial of strength and bid defiance to the laws of our country".

Toward the end of his dissent, in a section titled "Antidistortion" (meaning the court's and the government's previous position that it wanted to prevent corporations from distorting our governmental system), Stevens pulls out all the stops and lays out explicitly and at length the dangers corporations pose to the republic, taking a swipe at the court majority in the process: "The fact that corporations are different from human beings might seem to need no elaboration, except that the majority opinion almost completely elides it”. He goes on thus:

Unlike natural persons, corporations have "limited liability" for their owners and managers, "perpetual life", separation of ownership and control, "and favorable treatment of the accumulation and distribution of assets... that enhance their ability to attract capital and to deploy their resources in ways that maximize the return on their shareholders' investments" [...]. Unlike voters in U. S. elections, corporations may be foreign controlled. Unlike other interest groups, business corporations have been "effectively delegated responsibility for ensuring society's economic welfare”; they inescapably structure the life of every citizen. "“[T]he resources in the treasury of a business corporation', ” furthermore, “'are not an indication of popular support for the corporation's political ideas"” [...] “'They reflect instead the economically motivated decisions of investors and customers. The availability of these resources may make a corporation a formidable political presence, even though the power of the corporation may be no reflection of the power of its ideas'” (Stevens 2010; footnotes and case-law citations omitted.)

\subsection{Habermas's Deep Commitment to Rationality}

Habermas's communicative action theory is a deep commitment to rationality, which he maintains, contrary to postmodernism, is built into human communication a priori. Communicative action theory involves what Habermas calls a "linguistic turn" from subject-centered philosophy of Kant and modern Western philosophy to the speech act theory of J. L. Austin. This commitment to rationality is also a commitment to Enlightenment reason. In an essay titled "Modernity: An Unfinished Project", based on his 1980 acceptance of the Adorno prize, Habermas claims that, contrary to the holding of postmodernism, both modernism and the Enlightenment have yet to run their course (Habermas, 1997: p. 38). In fact, since the founding documents of the political system established in the United States, particularly the US Constitution and the Declaration of Independence, are direct products of the Enlightenment, Habermas's Enlightenment approach to politics and society should be welcomed here.

Habermas says rationality is inherent in communication, particularly as the function of communication is to help people reach understanding. Finlayson quotes an early translation of The Theory of Communicative Action, in which Habermas writes: "reaching understanding inhabits human speech as its telos" (Finalyson, 2005: p. 34). Habermas seeks to establish the rationality of the communicative process by what he calls "universal pragmatics", which argues that even before the content of any proposition is reached, there are always already separate rational commitments at work establishing social relationships. When we communicate, we implicitly make four validity claims: to the truth of a proposition, to rightness, to truthfulness, and to meaning, "and in speaking I am at least implicitly promising to be able to justify what I say and do, if challenged, on any of these four schemes" (Edgar, 2006: p. 165). A crucial feature of communicative action theory is the inter-subjectivity by which an actor recognizes in "the other" a being such as himself in a similar situation, making human interaction truly social.

\subsection{Rationality's Place in the Contemporary World}

Our contemporary world is ripe with rationality, particularly in science and technology, where is should be op- 
erative. And it thrives and flourishes in the realm Habermasterms the "system", where it is also not inappropriate for it to thrive. The problem, however, in Habermasian analysis, is that the realm of the lifeworld has been and is being rationalized by instrumental reason, which is not appropriate to lifeworld problems. In the lifeworld, instrumental reason is inappropriate, because as Pauline Johnson described it above, it's "a world in which all assertions, descriptions, claims, and propositions are contentious, open to criticism and review on the basis of their conformity to idealized and differentiated descriptions of their validity". In this world, according to Habermas, what is needed is discourse in which members of society come together communicatively to try to establish the norms by which they can pursue not the projects of goal-oriented organizations but the larger existential goals of a good life and the rules that govern it.

According to Habermas, communication in the service of these goals proceeds assuming that everyone is working in good faith and is knowledgeable about what is being discussed. When it turns out that those assumptions are counterfactual, communication stops and turns into "discourse", which operates on the basis of "discourse ethics" described above. In the Kyl example, when it turns out the Senator is communicating in bad faith, he is called on it, and discourse ensues. Kyl issued a clarification that at least showed he was distorting the truth. The goal of discourse is to re-establish the consensus, the agreement about norms, which allows communicative work to resume. Genuine communication was not pursued with Kyl, but one can imagine that in a society with a population trained in discourse and discourse ethics, the outcome might have been different from what it was in our society, where communication is marked by the instrumental uses of media, featuring public relations and the thirty-second sound bites, which too often dominate public communication. In a population sufficiently trained in such discourse, the Kyl statement on the Senate floor could well have been a career-ending scandal instead of the tiny blip it made in the news when it occurred before it was virtually forgotten. In a democracy, the education of the populace is what makes the system work, and for Habermas, education in how society actually works is the education that counts. No monarch, as Madison thought, would be needed to keep the system on track; an educated population would fulfill that function, and could well have ended Kyl's career.

\section{Conclusion: Rational National Political Discourse Is Possible}

This paper argues that it should be possible to consciously inaugurate a national discourse based on Habermas's ideas, that the best place to do that is in the Democratic Party (or in the opening created by movements such as the Arab Spring and Occupy Wall Street) augmented by social media and the World Wide Web, and that the proposed "faction" can model the Habermasian system in such a way that it will in fact do what Madison spoke of (at least in our misprision of) Federalist Paper No. 51: create "a will in the community independent of the majority that is [a will] of the society itself..." While such discourse obviously cannot start as "a will of the society itself", it can, through the functioning of discourse itself (through Habermas's discourse ethics), move in the direction of the ideals established by the best description of the lifeworld that our society has yet devised, beginning with the "Preamble" to the US Constitution, the Constitution itself, the Declaration of Independence, and continuing with the way that that project has been historically articulated into "our best values most grandly conceived", particularly in terms of civil rights, voting rights, and social security. There is much at stake, particularly as the "colonization" of the lifeworld by system forces proceeds unabated and there are few out-and-out advocates for the lifeworld. Habermas can teach us a lot more about democracy—and about how to practice it—-than what we have already known. Confucius has given us a standard for our discourse.

\section{References}

American Civil Liberties Union (2011). 2011: Voting Rights under Attack in State Legislatures. http://www.aclu.org/maps/2011-voting-rights-under-attack-state-legislatures

Bohman, J., \& Rehg, W. (2011). Jürgen Habermas. In E. N. Zalta (Ed.), Stanford Encyclopedia of Philosophy. http://plato.stanford.edu/archives/fall2014/entries/habermas/

Chan, W. T. (1969). The Humanism of Confucius. In A Source Book in Chinese Philosophy (p. 40). Princeton: Princeton University Press.

Edgar. A. (2006). Habermas: The Key Concepts. New York: Routledge.

Epps, G. (2011). Stealing the Constitution. The Nation.

Finlayson, J. G. (2005). Habermas: A Very Short Introduction (p. 56). New York: Oxford University Press.. http://dx.doi.org/10.1093/actrade/9780192840950.001.0001 
Habermas, J. (1997). Modernity: An Unfinished Project. In M. P. Entrèves, \& S. Benhabib (Eds.), Habermas and the Unfinished Project of Modernity: Critical Essays on the Philosophical Discourse of Modernity (p. 38). Cambridge, MA: MIT Press.

Habermas, J. (1974). Theory and Practice (p. 53). Boston: Beacon Press. (Translated by John Viertel, an Abridgement by the Author of His German 4th Edition Work, Published in 1971)

Hacker, J. S., \& Pierson, P. (2010). Winner-Take-All Politics: How Washington Made the Rich Richer and Turned Its Back on the Middle Class. New York: Simon \& Schuster.

Hall, D., \& Ames, R. (1987). Thinking Through Confucius. SUNY Series in Systematic Philosophy. Albany, NY: State University of New York Press.

Herszenhorn, D. M. (2010). Hold onto Your Seat: McConnell Wants Obama out. The New York Times. http://thecaucus.blogs.nytimes.com/2010/10/26/hold-on-to-your-seat-mcconnell-wants-obama-out

Johnson, P. (2011). Habermas: Rescuing the Public Sphere (p. 41). New York: Routledge.

Kennedy Jr., R. (2011). An Assault on Democracy. Reader Supported News. http://readersupportednews.org/opinion2/271-38/6525-an-assault-on-democracy

Mayer, J. (2010). Covert Operations: The Billionaire Brothers Who Are Waging a War against Obama. The New Yorker. http://www.newyorker.com/reporting/2010/08/30/100830fa_fact_mayer

Milton, J. (1644). Areopagitica: A Speech of Mr. John Milton for the Liberty of Unlicenc'd Printing, to the Parliament of England. http://www.dartmouth.edu/ milton/reading_room/areopagitica/index.shtml

Orwell, G. (1946). Politics and the English Language. Mount Holyoke College, Department of International Relations. http://www.mtholyoke.edu/acad/intrel/orwell46.htm

Packer, G. (2010). The Empty Chamber. The New Yorker, 47.

Plutarch (1952). Lives of the Noble Grecians and Romans (p. 87). Poplicola [Publius] and Solon Compared, Dryden Translation. Great Books of the Western World, Vol. 14. Chicago, IL: Encyclopedia Britannica.

Publius [Madison, J., probably] (1788). The Federalist Papers. The Avalon Project, Yale Law School, Lillian Goldman Law Library. http://avalon.law.yale.edu/18th_century/fed51.asp

Reagan, R. (1981). Inaugural Address. The American Presidency Project. http://www.presidency.ucsb.edu/ws/index.php?pid=43130\#axzz1ZdG9HAP2

Schmitt, C. (1996, 2007). The Concept of the Political. Chicago, IL: University of Chicago Press.

Seitz-Wald, A. (2011). Kyl Walks Back Planned Parenthood Claim: It "Was Not Intended to Be a Factual Statement”. Think Progress. http://thinkprogress.org/politics/2011/04/08/157415/kyl-walks-back-claim-about-planned-parenthoo/

Stevens, Justice J. P. (2010). Opinion of Stevens, J. Supreme Court of the United States. Citizens United, Appellant v. Federal Elections Commission. Ithaca, NY: Cornell University Law School.

Wang, Y. M. (1963). Instructions for Practical Living (pp. 27, 54). New York: Columbia University Press.

Wikipedia (2011). Shuowen Jiezi. http://en.wikipedia.org/wiki/Shuowen_Jiezi

Wikipedia (2014a). Astroturfing. http://en.wikipedia.org/wiki/Astroturfing

Wikipedia (2014b). Grover Norquist. Attributed to a May 25, 2001, Piece on National Public Radio Titled "Conservative Advocate”. http://en.wikipedia.org/wiki/Grover_Norquist (See also Bartlett, B. (2011). I’d Rather Be an Unlucky Ducky. In Economix (Blog). The New York Times. http://economix.blogs.nytimes.com/2011/09/27/)

Wolfe, A. (2004). A Fascist Philosopher Helps Us Understand Contemporary Politics. Chronicle of Higher Education. http://chronicle.com/article/A-Fascist-Philosopher-Helps-Us/20483

Wood, G. S. (2009). Empire of Liberty: A History f the Early Republic, 1789-1815 (Oxford History of the United States Series). Oxford: Oxford University Press. 
Scientific Research Publishing (SCIRP) is one of the largest Open Access journal publishers. It is currently publishing more than 200 open access, online, peer-reviewed journals covering a wide range of academic disciplines. SCIRP serves the worldwide academic communities and contributes to the progress and application of science with its publication.

Other selected journals from SCIRP are listed as below. Submit your manuscript to us via either submit@scirp.org or Online Submission Portal.
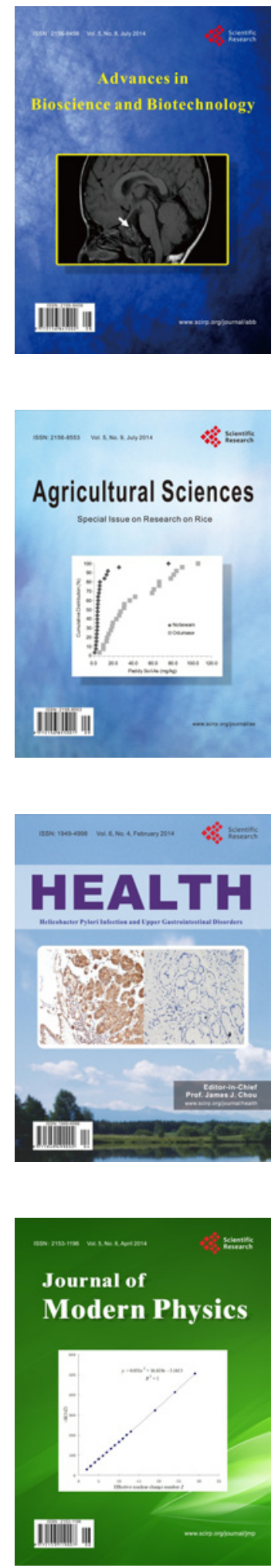
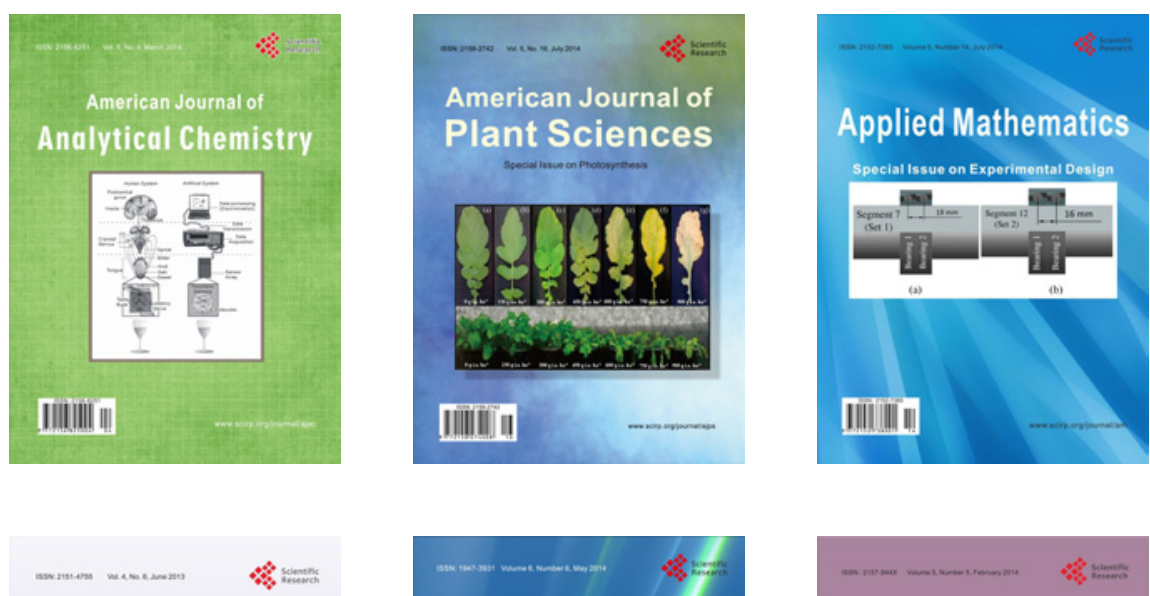

Creative Education
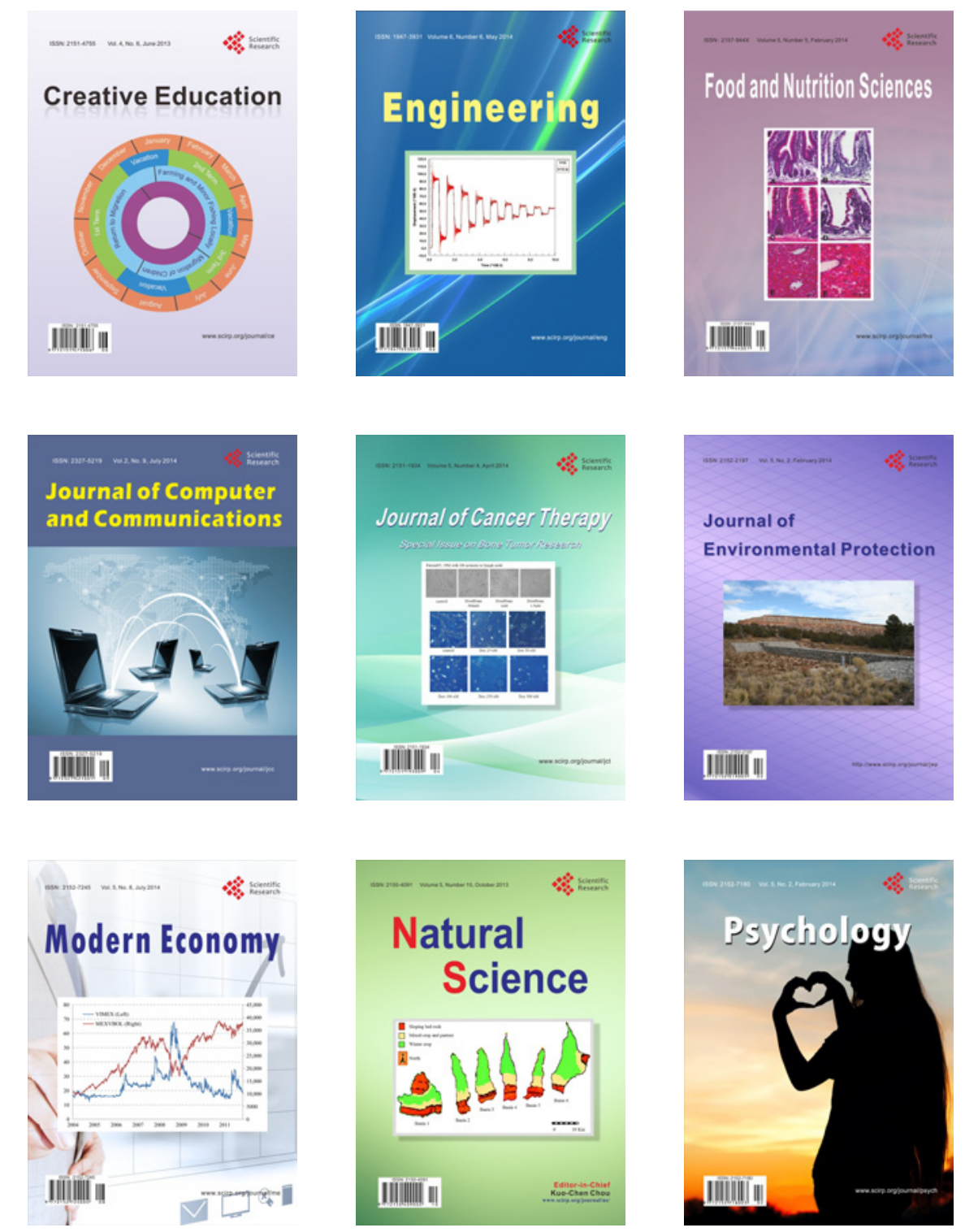